\title{
2. Wildlands, Deserted Bays and Other Bushy Metaphors of Pacific Place
}

\section{ALEXANDER MAWYER}

It is not only in the modern imagination that forests cast their shadow of primeval antiquity; from the beginning they appeared to our ancestors as archaic, as antecedent to the human world (Harrison 1992: 1).

In French Polynesia's Gambier Islands, contemporary Mangarevans have a disconcerting relationship with their islands' imputable wilds and forested spaces. Traditionally and generically referred to as the vao, these nature spaces were radically altered by a series of transformative ecosocial projects undertaken by Catholic missionaries beginning in the 1830s. These islands concurrently experienced a massive depopulation in the following decades. As a result, many previously densely inhabited and cultivated bays, and the slopes upland from them on Mangareva and other islands in the Gambier archipelago, acquired a shaggy veneer in categories of local understanding as no-longer and not-quite domestic terrain. A century later, regional government-sponsored forestry efforts only enhanced and amplified the landscape's transformation. If this is a pattern familiar in anthropological literature across the Pacific, it is nowhere more evident than in some of the Polynesian island groups of the eastern Pacific, where the demographic, social and cultural consequences of European contact were particularly stark (Dening 1988; Kirch and Rallu 2007). I suggest that the unfolding of this history at the intersection of these islands' nature spaces and its legacy in various aspects of local experience and understanding has been a process of de- and fraught re-domestication that casts a peculiar shadow on 
such ecosocial conceptions as 'forest' or 'wilds'. This chapter thus contributes to the observation in the works collected here that the forest in Oceania is not only an object of contemporary resource management, exploitation and human processes playing out over the long timescales of slow-life trees and their mature ecosystems, but also a historically inflected site of cultural being, social identity and the politics of the everyday with dynamic features over time.

Although it is hoped that some points raised here may be relevant to considerations of the forest across the region, my focus is solidly centred in the French pays d'outre-mer of eastern Polynesia and particularly in their southernmost group, the Gambier Islands. French Polynesia is an aqueous quasi-autonomous French dependency in the south-eastern Pacific. Its territory comprises five island groups, each distinct by geography, language, culture and history. The Society Islands are the regional centre, comparatively favoured by land area and population. Most of the Society Islands are high and lush with large lagoons that separate their main islands from the barrier reefs that encircle them. The regional capital, Pape'ete, on Tahiti, is in the windward south-east of the group and is now home to the vast majority of the territory's population, currently growing upwards of 270,000 (ISPF 2011). The Tuamotu Archipelago, previously called The Dangerous for its treacherous currents and submerged recifs, is the largest group by number of islands, nearly 80 atolls. Seen from the sky, these are circles of low coral islets on reefs that define large lagoons. The widely dispersed Austral Islands to the far south of the region are partly out of the tropics and famous for their artisanal productions and pre-contact ridgetop fortifications. Further to the north-east, and north of the Tuamotu, lie the well-known Marquesas, made famous by Melville's romantic tale of a sojourn in Taipivai Valley on Nuku Hiva and Gauguin's fauvist escapism on Hiva Oa. These are high islands with sheer and rugged coastlines but without the coral reef structures found elsewhere in French Polynesia - sometimes argued to have encouraged a high degree of isolationism and inter-valley conflict. To the south-east of the Tuamotu are the Gambier Islands, once an articulated volcanic structure in ages past, now several island fragments of which Mangareva is the largest within a single large reef structure notable for numerous low coral islets at different points along the reef. 


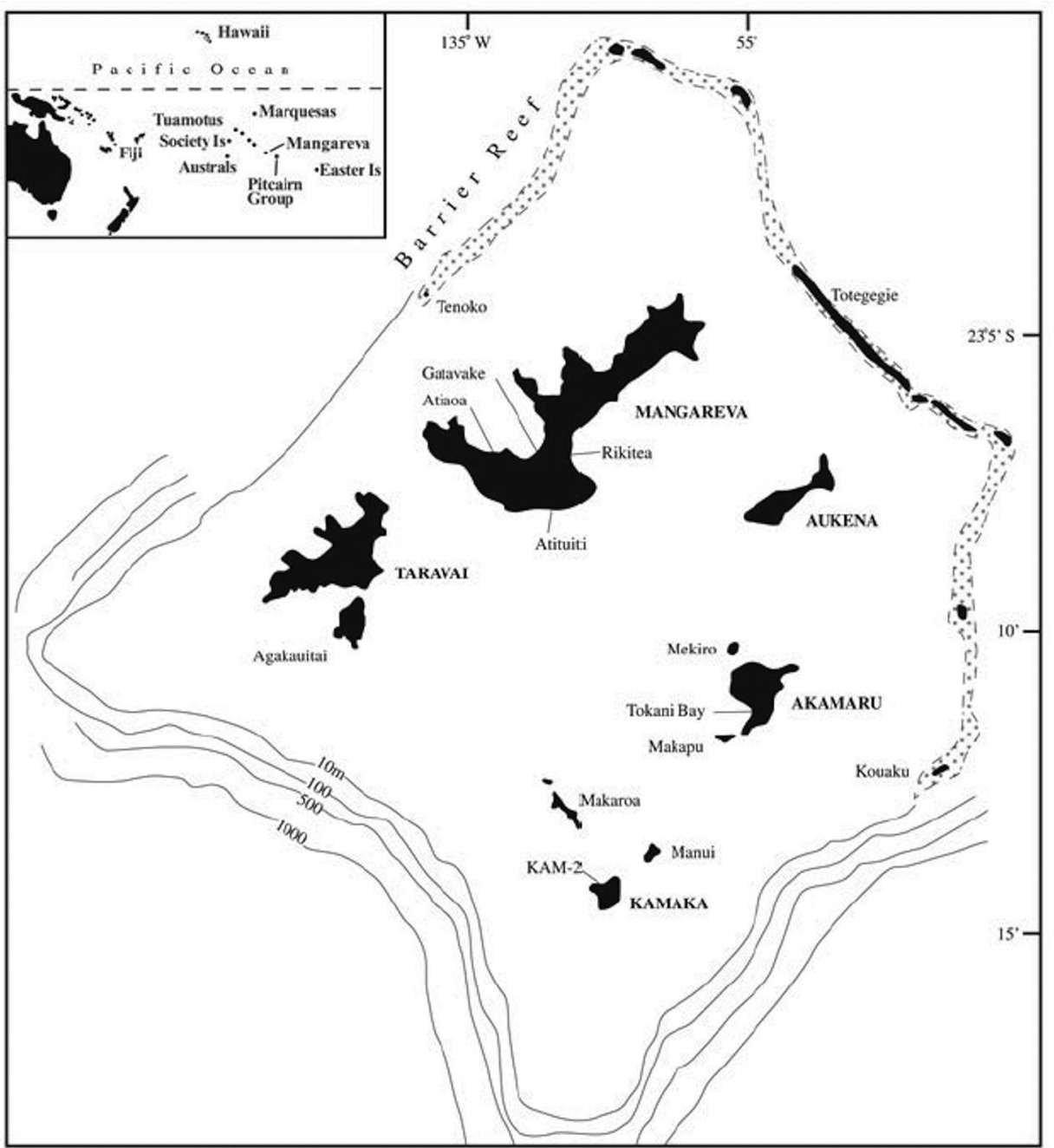

Figure 2.1 The Gambier Islands.

Source: Anderson et al. (2003: 120).

The Gambier rise from the oceanic deeps 1,700 kilometres south-east of the Society Islands. They are eight high islands amounting to 27 square kilometres of land surface and numerous motu (sand islands) or islets encircling a 90-kilometre barrier reef enclosing a vibrant coral lagoon. One notes that even such small islands as these have non-trivially varied micro-ecologies. Terrains including high grassed peaks, upland pine forests, complex traditional and neo-traditional downslope forests and highly varied near-shore house gardens and plantations. Motu on the fringing reef evidence well-established coconut plantations. Before contact with Europeans, all the islands of the chain were densely occupied, as were the sandy barrier islands, relative to their limited 
freshwater lens and the outlying atoll Temoe to the east of the group (Buck 1938; Laval 1938). Only the three islands of Aukena, Akamaru and Mangareva were inhabited between 1999 and 2009, the years between my first field visit and my last. Other islands in the group were home to a few families until the 1960s, while Aukena and Akamaru are home to only a few families today.

Today, however, the Gambier's population is burgeoning and beginning to push back into these formally (un)inhabited spaces, yielding encounters that can be both surprising and disconcerting in their historical inflections as families - whether youthful or mature couples - clear land for the first time in many decades, or in a century. What are contemporary wilds can turn out to have been someone's kaiga (domesticated lands) containing a house platform, boundary-marking sitting stone, or stonework structure of unknown utility. Apparent gnarly woods can also contain one or more charming French provincial quarried stone houses from the height of the Catholic instauration in the mid-nineteenth century, long abandoned and often forgotten, alongside stone ruins of earlier cultural complexes. Encounters with the material facts of historical displacements, discontinuities and gaps, lead contemporary Mangarevan landowners to ponder uncanny questions of historic loss over several different periods.

Moreover, the signs and sediments of history (Douglas 2009; Jolly 2009) are not limited to the artefactual or the architectural. Plant cultures too, often literally beneath one's feet should one walk along contemporary roads or into house gardens in any direction, or apperceived in the increasingly resplendent verdure of the quotidian, also reflect the struggles and counter-struggles of individuals in the receding past to make and remake the world-space of their home islands from the era of early European contacts, through the height of the colonial, and into the present through cultivation and gardening practices. This is visible not only in domestic landscapes surrounding today's 'akairiga (cohabiting family) homes; the contemporary wilds are also woven with cultures of the past, floral as well as material.

For instance, here and there in splendid isolation across the now wooded and bushy spaces of the high islands, often near visible remains of past dwellings or other structures, one finds aged coffee stands, a raspberry tangle deep in woods, soaring breadfruits, small groves of mature lychee trees, or surprisingly durable wild orange trees among other more modest food plants from mangoes to starfruits to tamarinds, many now evidently entangled in their use-rights. When these signs of past domestication are found on the back (tua) side of Mangareva, or in the bays of the smaller islands in an archipelago tragically depopulated a century earlier, their presence can be more than striking. With Douglas (2009) one notes that they offer enduring, hardy signs of the islands' histories and perhaps counter-histories at the intersection of plant and 
human cultures in the eastern Pacific. Individual fruit trees, berry tangles or a small stand of citrus or coffee in the midst of bush stand as silent sentinels of a prior social and ecological order.

Drawing on fieldwork in the Gambier since my own first arrival in these islands in 1999, when I participated in a land-clearing and restoration party organised by the Catholic Church on the then-uninhabited island of Akamaru, to working with two different households' land clearing, planting and home-planning practices in the summer of 2009, I suggest that Mangarevan understandings of the relationship of de-domesticated terrains and lands, te vao (the wilds), to domestic spaces, punui (habitation centres, towns), is in a period of significant flux if not confusion. An ambiguous quality of the landscape reveals something about the character of contemporary social life and culture in the Gambier, the active roles of the past in the present, and implications for the consideration of forest and other ontological objectifications of nature in the eastern Pacific.

By way of foreshadowing this chapter's subsequent sections, this work joins others that have articulated a profoundly warranted scepticism of the status of the category 'nature' across cultures and certainly in the eastern Pacific. As Descola (1996) and others have noted, critically in the Oceanic context by Hviding $(1996,2003)$, the broader concept of nature has a spectacularly overdetermined and thorny history in Western intellectual traditions in which some conceptions of nature are highly privileged, both universalised and, to hazard a low-hanging pun, naturalised (Collingwood 1945). Harrison (1992) alludes to this conceptual tangle in the epigraph above, observing the dualistic Western approach to forest as nonpareil stand-in for the category of nature in Western thought, the fundamental ontology of the forest as other-than-human, while simultaneously capturing the critical anthropological position that ontological categories of natural kinds are socially constructed as well as culturally construed. This is no less true in the Pacific where the concept of nature has a rich treatment in regional studies. Consider Smith's (1985) classic unravelling of the representation and conventionalisation of nature and the natural in the age of early European Pacific encounters. Famously, he noted that early European encounters in the Pacific imposed the perspectival and representational frames of voyagers on islands while simultaneously contributing to the emergence of new Western romantic and scientific naturalisms (Smith 1985). Attention to Pacific literature suggests that individual authors, both scholarly and otherwise, have often bumped into the obscure and distorting character of putatively universal categories and characteristics of 'nature' because of the evident murkiness of their place or quality in historical encounters. Notably, such attention has not generally percolated down to more material scales nor yet penetrated academic works across disciplines often relying heavily on ontological concepts such as beach, 
bay, lagoon or forest as natural categories in their sense-making about Oceania (Hviding 2003: 249). What, then, must be done to bring insular ecosocial kinds into critical awareness?

\section{Ordering the Gambier}

The kinds of forests dealt with ... belong to several different orders (Harrison 1992: 107).

While there are many distinct spaces of nature, and certainly a number of different understandings of and sentiments about nature in the Gambier, in company with the other works in this volume I focus on the ecosocial and ecocultural category of forest (forêt) or tiarakau because of the particular entanglement of imputable forested spaces in a range of critical collective issues in contemporary life. For instance, even something as fundamental as what counts as forest now has an active role in social processes in which Mangarevans construct and negotiate the making of selves and others. At the same time, the evident significance of the ambiguity of the underlying question of the object itself - what is forest? - reminds one of the continuing need for critical appraisals of 'nature' in the Pacific. Is forest a natural kind, that is to say, an ontological real? Or is forest an unnatural kind, yet another cultural imposition distorting anthropological attempts to make sense of Pacific lives and histories in terms of the material facts of the floral environment in the lives of the women and men for whom these islands exist as an immemorial home? Is there any such thing as forest in the Gambier, many copses and collectivities of trees notwithstanding? What might otherwise forest-seeming places be if not forest?

The concept of 'cultivated bay' is one starting point for considering the place of forests in anthropological sense-making in some islands of the eastern Pacific where upland slopes have sometimes figured (in European representations) as virtual deserts or, if perceived as forested, as undomesticated wildlands. ${ }^{1}$ One notes the privileged position of this ecosocial category as a way to frame the intersection of culture and nature in Pacific archaeology, anthropology and history, and as the calibrating model of social order and island emplacedness. In the Mangarevan case, this is evident in Te Rangi Hiroa's (Sir Peter Henry Buck's) superlative Ethnology of Mangareva:

\footnotetext{
1 Alternatively, one might start with the concept of 'beach'. Indeed, just as forest is the nonpareil standin for 'nature' in Western ecosocial conception, so beach might be argued to be the nonpareil stand-in for island natures in much Pacific anthropology and history. That so much superlative work has been devoted to recognising and remaking the understanding of the beach as a site of social and cultural encounter from Malinowski (1984 [1922]) to Dening (1988) and beyond, as in Jolly et al. (2009), perhaps only underscores the need for further examination of its ontological status as a site of and in nature in its own terms, while highlighting the need for attention to other 'natural' spaces of the islands.
} 
The bay lands, desirable as sites for dwellings and beaching places for canoes and rafts, with the introduction of cultivable food plants became extremely valuable, for it was only in such alluvial ground that the breadfruit, coconut, and banana could thrive. Such land was limited in extent and became vastly desirable. The desire for its possession created innumerable struggles and, apart from blood feuds, the dominant motive among chiefs and warriors was to obtain a share of cultivable land to give them a richer food supply. The introduction of cultivable food plants raised the standard of living for those fortunate enough to acquire cultivable lands, while the wild plants of former days formed the complement (kinaki) to fish for the poor and the masses. The desire for better vegetable foods led fishermen to the economic pursuit of exchanging fish for preserved breadfruit. Cultivable foods, kaikai 'akariki (foods of kings or high chiefs), and wild foods, kaikai a te oge (foods of the hungry) became associated with the cleavage in social position between landowners or cultivators and the common people who were without cultivable land. (Buck 1938: 199)

On one hand, Buck offers nothing less than a penetrating anthropological model of the intersection of nature, culture and social order, well supported by the facts on the ground in numerous works from across Oceania. On the other hand, one might ask how does and does not 'cultured bay' map onto locally significant paradigms of human dwelling-in-place as the intersection of locally salient formulations of the spatial relation of nature and culture as gnati (bay, tribe), nuku (maternal lands) and kaiga (personal lands) in which the biosocial and the genealogical is mapped into the geophysical terrain that extends past the perceived-as-cultivated limits of bay spaces? How do such models as Buck's ignore or displace the margins of both cultivated and evidently non-cultivated spaces, boundaries between ecosocial zones to which a category of forest in eastern Polynesia may in some ways belong? Are they ethnographic objects to which sufficient attention has been paid in their own terms?

The area of cultivable land was small in comparison with the size of the islands, and lands and their produce were held by the ruling families and landowners who had been rewarded for services rendered in war. A large number of the common people having no cultivable land at all were thus denied direct access to vegetable foods, such edible wild plants as grew on the promontories and hillsides beyond them was the sea, which they tilled assiduously. A large portion of the commoners depended for the necessities of life on fish, shellfish, crustaceans, and such edible wild plants as grew on the promontories and hillsides beyond the boundaries of the cultivable lands. (Buck 1938: 197)

Again using Buck as a stalking horse - with no intention of suggesting his work as anything other than exemplary of a standard model of the natureculture intersection from his anthropological era to the present - one might conclude that although wild land (including 'forest') is present in his model, 
its presence is largely context for a foundational position on human mastery and dominion over the landscape, centred on cultivated bays and ocean spaces in contrast, if not opposition, to imputed island-interior wildlands.

The flora of Mangareva is disappointing. The steep slopes of the hills combined with the rocky soil are not conducive to luxurious growth. The scarcity of the flora is stressed by traditions that, when first peopled, the land was bare of trees from the beach to the foot of the hills, and that trees as well as cultivable food plants were introduced later by Tupa. (Buck 1938: 8)

While Buck addresses the situation and character of plant cultures early in his studies, his focal arguments rest on a native/introduced division of flora, and by the social relationships mapped onto distinctions in access to lands producing kaikai 'akariki, the chiefly foods cultivated in near-shore plantations owned by togo'iti elites in the pre-contact Gambier, as opposed to kaikai a te oge, six wild foods found on the upland and, from his point of view, non-domesticated spaces of these islands, normally only consumed by commoners.

Following the position established by Hau'ofa (1993) in other analytical domains, nature in the eastern Pacific perhaps seems meagre or too thoroughly domesticated and controlled, hence easily bracketed relative to continental chauvinism and the infelicitous baggage of Western intellectual traditions. For instance, that island spaces have diverse histories of use has been long evident in the anthropological literature. Yet a pervasive myth of the pristine hovers over many island spaces, a perverse legacy of the history of the Western romanticism of Pacific nature implying that domestication of the island ceased at some more or less arbitrary social boundary beyond which were wilds, and that many or all of these ecosocial spaces were fixed in extension or duration on the landscape. ${ }^{2}$ In fecund reality, Pacific landscapes and ecologies were and are highly varied and may too often have been conceived in reductionist terms, as in Buck's categorisation of the Gambier's vegetable biofacts (Table 2.1).

The presence of a floral chauvinism evident in the history of the interpolation of the Gambier into Western scholarship via Buck's Mangarevan work is a case in point with his insistent focus on economic flora and human domestication. Notably, what makes some flora economic is nowhere defined. The utility of 'utility' as an analytic is taken as a given. Foremost, it offers Buck the means to undergird his interpolation of Mangarevan forms of rule and sociopolitical identity into a comparative anthropology, ultimately by grounding the distinction between common and uncommon classes in society in large part in terms of their relations to land and its produce. Landowning cultivators are ragatira or togo'iti (Buck 1938: 200), social elites who are authorised and

2 See also Hviding, Chapter 3, and Bell, Chapter 6, this volume. 
legitimate possessors of useful, economic plant cultures largely imported during settlement periods and long domesticated. Contrastively, 'urumanu (commoners) subsist on the fruits of the sea and what Buck labels kaikai a te oge, foods of the hungry, during lean times and good. Commoner engagements with, and use of, wildlands is relegated to an afterthought despite the evident significance of that part of the landscape in regularly supporting the many (Buck 1938: 215).

Table 2.1 Buck's categorisation of the Gambier Islands' vegetables.

\begin{tabular}{|c|c|}
\hline \multicolumn{2}{|l|}{ Native plants } \\
\hline 'ara: Pandanus sp. & pokea: Portulaca lutea \\
\hline gegie: Suriana maritime & potini: an edible fern? \\
\hline kokini tekeo: Tephrosia purpurea & to'ira: Cyperus pennatus \\
\hline \multicolumn{2}{|l|}{ koueriki: Terminalia koariki } \\
\hline \multicolumn{2}{|c|}{ Plants introduced by Polynesian settlement } \\
\hline 'au: Hibiscus tiliaceus & miro: Thespesia populea \\
\hline ere'i: Cocos nucifera (coconut) & nono: Morinda citrifolia \\
\hline $\begin{array}{l}\text { eute, pure: Broussonetia papyrifera (paper } \\
\text { mulberry) }\end{array}$ & pia: Tacca pinnatifida (arrowroot) \\
\hline rama: Aleurites oluccana (candlenut) & gatae: Erythrina sp. \\
\hline rautea: Ipomoea sp. & kape: Alocasia macrorrhizos (taro) \\
\hline rega: Curcuma longa (turmeric) & katiru: Cucumis sp. \\
\hline tamanu: Callophyllum inophyllum & ke'ika: Eugenia malaccensis (mountain apple) \\
\hline taro: Colocasia esculenta var. antiquorum & ko'e: Schizostachym glaucifolium (bamboo) \\
\hline ti: Cordyline terminalis & to: Saccharum officinarum (sugar cane) \\
\hline kumara: Ipomoea batatas (sweet potato) & tumei, mei: Artocarpus incisa (breadfruit) \\
\hline 'uatu: Musa sp. (plantain) & meika: Musa sp. (banana) \\
\hline u'i: Dioscorea bulbifera (yam) & konini kai (edible creeper, not collected) \\
\hline aoa: Ficus umbilicata (banyan) & kaka'o: Miscanthus japonicus (cane) \\
\hline
\end{tabular}

Source: Buck (1938: 9).

What might be thought of as forest as an ecosocial kind, in the normal sense of woodlands and wilds, a site for a certain kind of human encounter with nature in the Gambier, is thus in some sense defined out of existence despite the evident significance of wildlands to commoners (and togo'iti in lean times) after the early settlement period commencing with the arrival of the culture-hero Tupa, but before contact with European cultures. Lands are figured as either fully domesticated or fully wild (i.e., not economic, not playing a role in supporting social status). This is a characteristic dichotomy that I suggest deserves further examination across the eastern Pacific and Polynesia more broadly in classic works as well as more recent examinations of island ecologies. 


\section{Reordering the Gambier}

The story of the Catholic instauration in the Gambier, a putative theocracy that re-architected these islands from the foundations up, has been told and retold since the mid-nineteenth century (Delbos 2002). The basic outline of the European interpolation of the Gambier into the nineteenth-century world system and Catholic development of Mangarevan society and lands, prefiguring effects on nature, can be quickly summarised. Within years of the 1834 arrival of evangelical and evidently extraordinarily charismatic priests, including the infamous Péres Laval and Caret along with an Irish lay brother, Catholicism was embraced by one of the main chiefly parties of the era, and used to solidify and consolidate the rule $(a o)$ of the archipelago in a period of significant tensions between different chiefly families as well as within the royal line of the 'akariki nui. This consolidation of power under the renewed paramount authority of the singular 'akariki Te Maputeoa was spectacularly good for the mission and, if too transiently, for Te Maputeoa. The new order resulted in imputed improvements to the material infrastructure of the islands as well as the establishment and regulation of authority over the numerous traders, merchants, beachcombers and pearl exploiters, who had been arriving in ever-greater numbers, year after year, since the 1820s.

Practically, for Europeans arriving in the Gambier in the mid-1840s, the instauration then still in progress seemed a Pacific miracle, as if a provincial French village had been transported to the eastern Pacific, about as far from a continental landmass as is possible on this terraqueous globe. The impressive list of architectural feats achieved over mere decades by the population probably does little to convey the experience of then contemporary arrivals. The 2,000seat cathedral in Rikitea, four other stone churches each capable of seating many hundreds, a two-storey, many-roomed college and seminary, the convent, prison, king's tower, chapels, stone-paved roads, quays, numerous follies including massive triumphal arches, and over 50 massive hand-quarried, facedstone homes on a French provincial style, many of two storeys (Vallaux 1994).

The arrival of new food crops was, for Mangarevans at least, no less spectacular. Indeed, a key feature of the re-architecture of the islands was the establishment of new plantations, often in cultivation zones not previously used for what Europeans recognised as agriculture, the so-called wilds where kai oge or ono oge were harvested by 'urumanu. Parts of the island not previously domesticated, as the term might have been conceived by Buck, were transformed or, perhaps, re-domesticated. Simultaneously, and perversely, parts of the islands previously highly domesticated, gnati sites of settlement, were de-domesticated, moved out 
of the category of punui village spaces into vao wilds or mataeina' $a^{3}$ (agricultural spaces) as the demographic tragedy of the decades between the 1820 s and 1860 s played out. These transformations contributed to, or played a role in, revaluations of ideas about domesticated and wild spaces in the archipelago.

With retrospective acuity, Delbos in his excellent La Mission du Bout $d u$ Monde: La Fantastique Aventure des Bâtisseurs de Cathédrales dans l'Archipel des Gambier (2002) argues that the Catholic spiritual instauration, the social and political reorganisation of the population, the implementation of the rule of law, and the stabilisation of the pearl trade were all a by-product of the architectural mission. It is as if the organisation of labour necessary to erect the edifice of the mission was self-fulfilling in realising the mission as a reordering of the social relations of the tribal groups along Western lines. Ati, as labouring units, no longer were to be conceived as established or grounded by their ritual and practical connection to specific kaiga and the breadfruit groves and storage pits ritually maintained therein, but by their orientation to and material maintenance of particular church structures in particular districts, including new plantations. Importantly, the massive cathedral was conceived and achieved as a collective labour by competitive work groups drawn from across the ati. The re-architecting of the legal realm operated to support and bolster the reorganisation of the social realm around labour rather than around kin relations within ati and shared connections to breadfruit groves and specific terrains, named and collectively utilised and literally incorporated into/as descent groups. Importantly, the reordering privileged more varied personal or individuated gardening around homesteads ('are 'akairiga) as well as greatly expanded cultivation.

The more the mission built, the more it required the fabric of Mangarevan culture, society and land to shape itself to the building of the mission, and the more the mission could build. ${ }^{4}$ The more it cultivated, the more it could cultivate - culminating in the establishment of orange groves, a significant raspberry plantation and widespread coffee plantations, among other wildly new cultivars. Within years of its instauration, Mangareva was widely discussed in a number of maritime and Catholic and mission journals and papers, especially

\footnotetext{
3 Modern, borrowed from Tahitian.

4 There were many forms of spatial transformation parallel to the translation of previously vao spaces into newly 'domestic' plantations. For instance, the chief's dwelling was reconstructed as a king's tower and palace (conserving the structures of power within the same line of descent while transforming the tokens and conceptions of that power along European lines), the traditional circum-island ara was cobbled and converted into the Ara Nui (privileging island traffic along a mua/roto axis as never before) and part of the terrain of and below the royal nurseries Te One was converted into the convent Rouru (maintaining while transforming the gender and sanctity of the land).
} 
after d'Urville's visit, and praised for the rapidity and totality of the mission's achievements - compare Goyau's (1928) summary of the vast and varied nineteenth-century commentary.

Delbos (2002) draws attention to the process by which Mangareva, a 'New Paraguay' as it was seen by visiting dignitaries beginning with d'Urville, Moerenhout and others not a decade after the commencement of the mission, was effected because of the curious dovetailing of the architectural and engineering skills, presumably coincident to their spiritual talents, possessed by several of the key figures of the early mission. The mechanics of the transition from a stoneage society to a model Catholic community, he argues, were concretely achieved as architectural project. Mangareva became, as he puts it, a land of bâtisseurs (builders). This may well have been the case, but I note it was also becoming a land of jardiniers (gardeners) - compare Laval (1968) for numerous anecdotes regarding the influence of introduced cultivars on the overall success of the mission. Thus the westernisation of the islands was also a re-domestication, a process of reordering nature in culture that was characteristically individuated (non-collectivist), democratised (the disestablishment of chiefly privileges over kai 'akariki alongside the vast expansion of available cultivars), and an expansion of domestic lands and subsequent if temporary diminishment of the wilds. Initially vao spaces became domestic plantations for new foodstuffs that greatly expanded and enhanced the kinds and numbers of domestic groves on the island even as traditional socially foundational near-shore breadfruit groves receded in significance and collective utility and were eventually abandoned.

But the autopoietic success of the mission as a total reinstitution of Gambier society was not without its dark irony. Even before the beginning of the instauration, and continuing throughout the entire middle of the nineteenth century, the Mangarevan population declined dramatically. By the time the last bricks were being installed at the tops of the cathedral and church towers, the keystones placed, the arches erected, the new plantations of coffee and raspberry and orange established, there were scarcely persons enough to fill one of the four churches, much less the cathedral (Vallaux 1994; Kirch and Rallu 2007). Meanwhile, commercial interests on the island, centred on the pearl and reprovisioning trades for passing navigation, began to chafe under the impositions of the Code Mangarévien - essentially a Western legal support to the total architectural institution of the mission which sought among other things to co-opt labour for the slightest material or spiritual transgression. Ultimately, and almost simultaneously, the mission project and the chiefly ao (rule) of the Gambier collapsed under the tensions of the demographic tragedy. New wilds grew up and subsumed all of these works, architectural or vegetable, engendering new forms of ecosocial space. Lands only just (re)domesticated over 
the previous decades now returned to, or became, wilds or vao. What might have seemed an expansion of wildlands appears a process of de-domestication of previously thoroughly human spaces.

\section{Wildlands and Forests}

During the early middle ages the northern forests of Europe were vast, stretching across the continent like domes of darkness and the indifference of time. Interspersed throughout them were smaller or larger settlements lost in the shadows of antiquity's decline. With respect to the medieval social order that was reorganizing itself on the basis of new feudal and religious institutions, the forests were foris, 'outside'. (Harrison 1992: 61)

The extensive anthropological literature on culture and ecology in the Pacific has generated a number of enduringly potent arguments. Yet, a centring glimpse forward and back from exemplary mid-century texts such as Goldman (1955, 1957, 1958) or Sahlins (1958) suggests that external commentators have privileged the adaptive, ecologically canny, masterful character of the human-ecological interface on many remote Pacific islands with respect to the role of ecology in political and social organisation, particularly complexity and stratification. Professional and amateur observers alike have often been profoundly influenced by and made much of such claims along the lines of 'look what they have done with so little' from the age of early contacts with European voyagers, through the ecological turn in mid-century Pacific anthropology, and certainly such perspectives are shot through contemporary archaeological framings of the region. Moreover, such a perspective is often imbued in works, including by the same authors (cf. Kirch and Sahlins 1994), that considered the sociocultural and political transformations engendered by the sandalwood rush in the eastern and central Pacific in the early nineteenth century, the first post-contact era inter-island interpolation of Pacific forests into global trade, as exemplary of human dominion over island natures.

Certainly this position has its attractions. Who would not thrill to the story of the (pre/post) Lapita conquest of ocean and its lands and seaways (Kirch 1989, 2002)? But it may also be a remarkably enduring form of romanticism, a framing narrative that directs the kinds of questions we ask of others, of our field data, of our works. As has now been thoroughly discussed, Western scholars of others' cultures project our fundamental ontological categories of nature space at significant analytical risk (Descola 1996; Selin 2003; Lotz 2005; Escobar 2008). Broadly circulating invocations of nature as where man is not or where culture is not and of island spaces aside from 'cultured bays' as wildlands, abcultural 
or boundary-cultural spaces useful only for purposes of resource extraction of famine (undomesticated) foodstuffs and certain material resources, place anthropological analysis at particular risk.

In conversation with this literature - importantly Hviding (1996: 170), who notes that a wild/tame analytical pair can be enhanced by a sensitivity to degrees of domestication - this chapter has been drawing attention to the analytical utility of locally diverging notions of used and unused, inhabited and uninhabited, cultivated and uncultivated spaces, significant in the fashioning of place and person, as a potential amelioration of the ontological challenge of mediating 'nature' and 'forest' in anthropological sense-making. In the Gambier, the paired terms punui and vao, domestic space and wilds, offer a meaningful distinction that can perhaps serve to tease out a meaningful sense of forest among other contemporary vao spaces. The relevance of this pair is that it can be evaluated in terms of a domesticated-undomesticated distinction with an imputable pan- or meta-cultural interpretability. Acknowledging that the presence of humans on the landscape (or seascape) fundamentally disestablishes claims that nature, or forest for that matter, is where man is not (Vogel 1996; Hull 2006), I note that domestication offers a gradient, non-absolute, conceptual framework for making sense of nature's spaces in and across cultures. In essence a process, not a static state, as an analytical framework, domestication reflects the reality of biological and human cycles in time.

In the Gambier, contemporary Mangarevan understandings of the relation between highly charged social spaces and equally charged absocial island spaces are categorised in the punui/vao pair. The category of punui is relatively unproblematic: (1) a village, a town; the chief settlement or capital (Tregear 1899) or n. ville, village; endroit principal d'un pays (Rensch 1991). The word vao, however, is somewhat more nuanced: (1) uninhabited lands; lands unplanted and uncultivated, (2) a plain; open country without trees, (3) relationship; family (Tregear 1899). ${ }^{5}$ Or, in Rensch's (1991) French/Mangarevan dictionary: Vao n. champ, endroit; terre non habitée et non plantée; clan, tribu. Intriguingly, punui does not appear to contain a semantic field relation to the concept of consubstantial sociality or group membership, while the category of vao does. In this sense the semantic pair for vao is ati/gnati - a Mangarevan synonym that means at once 'bay and people'.

Here is the rub. How can both domesticated space and undomesticated space overlap with semantic conceptualisations of a human group, an 'us'? How does this semantic inconsistency complicate such nature-society divisions as evident in Buck's model above? The possibility that vao society was constituted by ati 
disposed of desirable domesticated baylands and forced only to live on kai oge, meagre wild foods, is specifically excluded in all ethnographic accounts of the archipelago, including those by Buck. The answer, I learned from a number of senior Mangarevans, is still very much in memory and, somewhat, in practice. Traditionally, vao would not be used to refer to one's own group or to the groups of others in polite conversation. Vao space is 'other space', both in the sense of Buck's putatively undomesticated wild and in the sense of other people's lands to whose domestic fruits one is not entitled. Wildlands call into mind, from the perspective of some discursive context in which questions of personhood and collective belonging is at question, wild others. One's own group is always and only one's ati (gnati).

That Mangarevans' notions of domesticated/undomesticated lands were also mapped onto differences between human groups is highly consistent with Hviding's argument that a lack of cognitive dichotomy between the human/non-human characterises Oceanic views of 'nature' (2003: 259) and is ethnographically comparable to the Morovo case, in other ways culturally quite distinct, among whom the notion of puava (territory) 'does not constitute a distinct realm of "nature"' (1996: 170) vis-à-vis notions of collective identity, group membership or being butubutu (gens).

When I asked a group of friends in the summer of 2009, senior fixtures in Mangarevan society, e aha te makararaga o te 'u teito o te vao? - what are the thoughts of the ancestors about the vao? - two very different comments emerged over the course of an interesting conversation. First, as one man put it, a tau ara (at that time) Mangarevans 'lived so close to nature, there was no difference'. ${ }^{6}$ He explained that a group somehow equates to its vao, its place in nature; a sense that the people of the past were in such a relation to their lands as to be categorically themselves others, in effect not his people. This is an extraordinary claim, I believe, one that is highly revelatory about his sense of contemporary practices and relations to the landscape as alienated from some imagined more authentic connection with lands now somehow displaced. Other participants pointed to another sense. As another man put it, 'crossing lines is dangerous', e tinai ona; one can be struck and killed, further highlighting the implied distance - in time, space, social relation - between the honoured tupuna (ancestors) and their contemporary inheritors. Vao spaces were a metaphorical line between the culture of one's own people and the dangerous other, whether human or natural or divine.

6 Note that my informant used 'they', not 'we', as he often did when speaking of tupuna ancestors. 


\section{Displaced Natures}

If it is true that the post-Christian era detaches itself from the past, frees itself to some extent from the inertia of tradition, 'comes of age' under the auspices of reason, it is also true that it experiences its freedom as a deprivation as well as a gain. Early in the last chapter we saw how freedom from the past implied freedom for an enlightened future. The countercurrent of Enlightenment's drive to inherit the future is nostalgia. As the ancestors fall silent in their graves; as the age-old traditions and landscapes of the past recede into vanishing horizons; and as the sense of historical detachment begins to doubts its original optimism - nostalgia becomes an irrevocable emotion of the post-Christian era. (Harrison 1992: 155)

Long before the mantle of the nuclear age was draped - in French red, white and blue - over the Gambier in the 1960s, with various sorts of fallout once again altering the local understanding of social-human spaces and wildnatural-dangerous spaces in the Gambier, these islands were already sacrificed with other east Polynesian archipelagoes on the altar of history. Ship-to-shore vectored diseases, the transformation of social organisation during the Catholic instauration and increased mortality from commercial pearl diving all bespeak a nearly unimaginable human tragedy. But even in the absence of a concrete accounting of demographic casualty, we can be quite certain that the population saw a 40-year decline beginning in the mid-1820s, when a difficult to estimate population would have been reduced by more than 60 per cent and perhaps greater than 90 per cent (Kirch 2007; Kirch and Rallu 2007). Careful records of Mangarevan births and deaths were instituted in the heyday of the mission and record the population decline in great detail until the 1870s, after which the population largely stabilised. For instance, a population of approximately 1,500 in 1863 had become 446 by 1881, and one notes there had already been several major epidemics before 1863, including one prior to 1834 which may have killed half the population at that time (Laval 1968). Also, it is not clear in the missionary census records - the chief source of pre-1881 demographic information whether Rapa Nui and other Polynesians who at various post-contact periods constituted a significant portion of Gambier society were ever enumerated, although European, Chinese, Demi and non-Polynesians generally were. ${ }^{7}$

By the 1860s, about 500 persons still lived in the archipelago, some of whom had started life elsewhere in the eastern Pacific. Notably, this remained the stable population point until the 1980s, when the total number of inhabitants began to increase. At times, chatting with friends and other informants, it

7 Thus, while empirical, the question of whether the numbers in the early records indicate the actual Mangarevan population or all 'native' Polynesians remains intractable. If the recorded population figure includes all Polynesians living on the island, the specifically Mangarevan population must have been very small indeed. 
seemed my fieldwork in a period of rapid demographic expansion was a postapocalyptic anthropology, as the visual, auditory and even tactile trace of a past that had somehow not become the present regularly confronted me, so many memento mori in the words of informants, particularly when working with folks to clear a plot of forest for a house site, garden, old roadway, lands around one of the useless beautiful stone churches, or for aesthetic purposes. One might well say that contemporary Mangarevans, like their cousins on Rapa Nui and in the Marquesas, are uncertain descendants of survivors of the end of a world and at times in everyday conversations they seem conscious of it, and no more than when confronted in the bushy landscape by the architectural ruins of the Catholic mission alongside even more ancient stone ruins of the pre-Christian era(s).

Indeed, by the time the French nuclear test establishment, the Centre Experimental du Pacifique, established a large footprint in the Gambier in the mid-1960s, identified by Mangarevans as a critical watershed in their relationships to their island's ecospaces, the hand-cut stone pavements of the cross-island roads were showing immense neglect, few families lived outside the two punui previously constituted as competing high chiefdoms but consolidated after European arrival, and many people were already living exclusively in Rikitea. The watershed was much earlier, however. At some point after 1920, the traditional corporate descent groups called ati, which served as the primary frame of social organisation, finally dissolved into a small number of closely related families — today, a proverbial witticism suggests there may be only three. By the 1920s, dusk had settled on the marvels of the Catholic instauration that had earned the Gambier international fame in the mid-nineteenth century, the abbey finally emptied, the college abandoned, and the draughty and ageing stone houses left for newer 'plantation' style wooden houses. These houses were in turn abandoned in the last decades of the twentieth century for more contemporary concrete structures, although two or three of the dilapidated wood structures can still be seen, including the mothballed childhood home of the French Polynesian president Gaston Flosse.

One result has been that Mangarevan understandings of the relationship of non-domesticated space and lands, te vao, to domestic spaces and human places, te punui, have changed. For much of the past two centuries, many of this archipelago's spaces have increasingly been perceived as 'brousse', 'scrub', 'bush' or 'forest'. This process peaked when the establishment of the French nuclear test regime in the nearby atolls Mururoa ${ }^{8}$ and Fangataufa in the 1960s saw the end of any remaining intensive plantation agriculture along the de-peopled coasts. Concurrently, the population was reconcentrated in a single village adjacent 
to a hastily erected nuclear fallout shelter after fallout events in 1966, results of France's Pacific nuclear establishments (CESCEN 2006). At the same time, many of the previously densely inhabited and cultivated bays, and the slopes upland from them on Mangareva and across the archipelago, were subjected to an intensive and dramatically efficacious forestation project promoted and partially implemented by the regional administration's Service de l'Agriculture (Vallaux 1994: 127). In less than four decades, as visible in Figures 2.2 to 2.6, the long unfolding de-domestication of a substantial portion of the archipelago was finally consummated by a forestry project that seeded many of the upper slopes of the islands with successfully invasive pines, and sometimes more colourful Albizia lebbeck and Albizia falcata, greatly decreasing the ease of travel between bays or across the spine of the mountainous ridgeline and literally obscuring the face of the land.

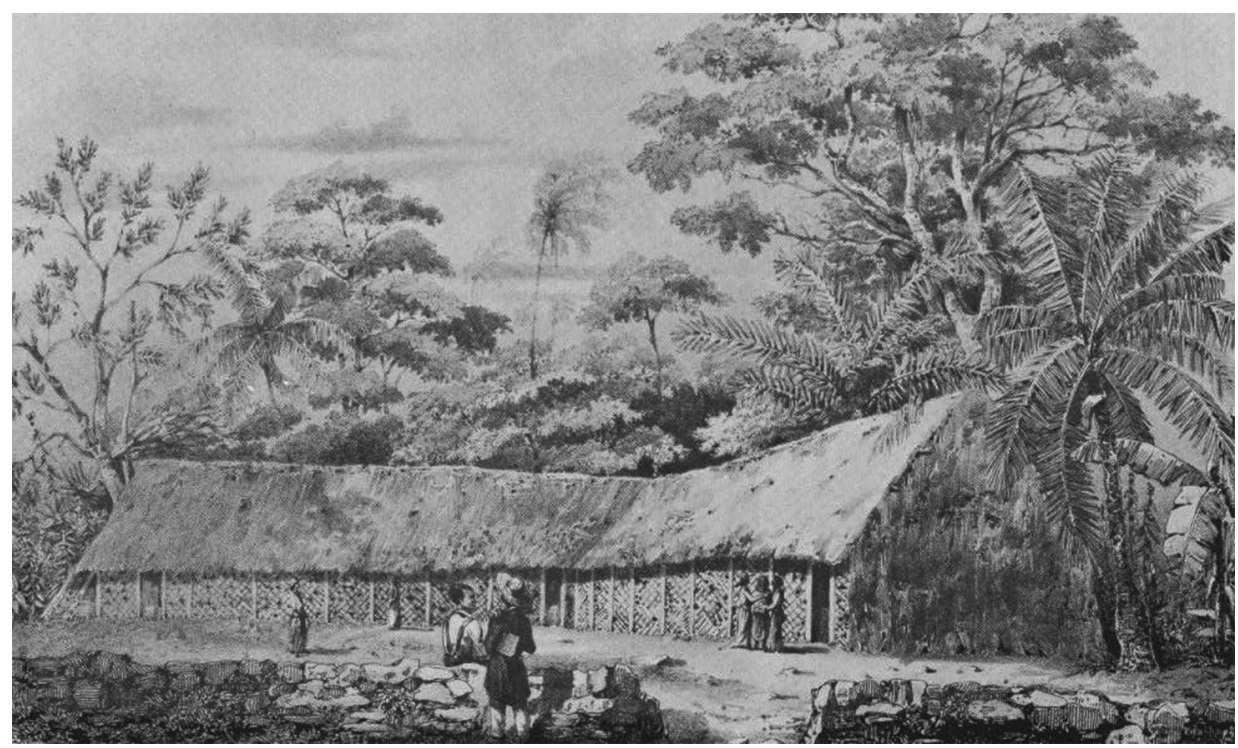

Figure 2.2 Scene of near-shore cultivated bay lands on Mangareva at the time of d'Urville's visit to the Gambier, by Louis Le Breton, 1842. The rich, readily recognisable near-shore domestic plantations contrast with the dry, low-coverage upland slopes on all the higher islands of the Gambier at that time.

Source: Plate no. 42 in the Atlas Pittoresque of J. Dumont d'Urville's Voyage au pole sud et dans l'Oceanie sur les corvettes l'Astrolabe et la Zelee. 


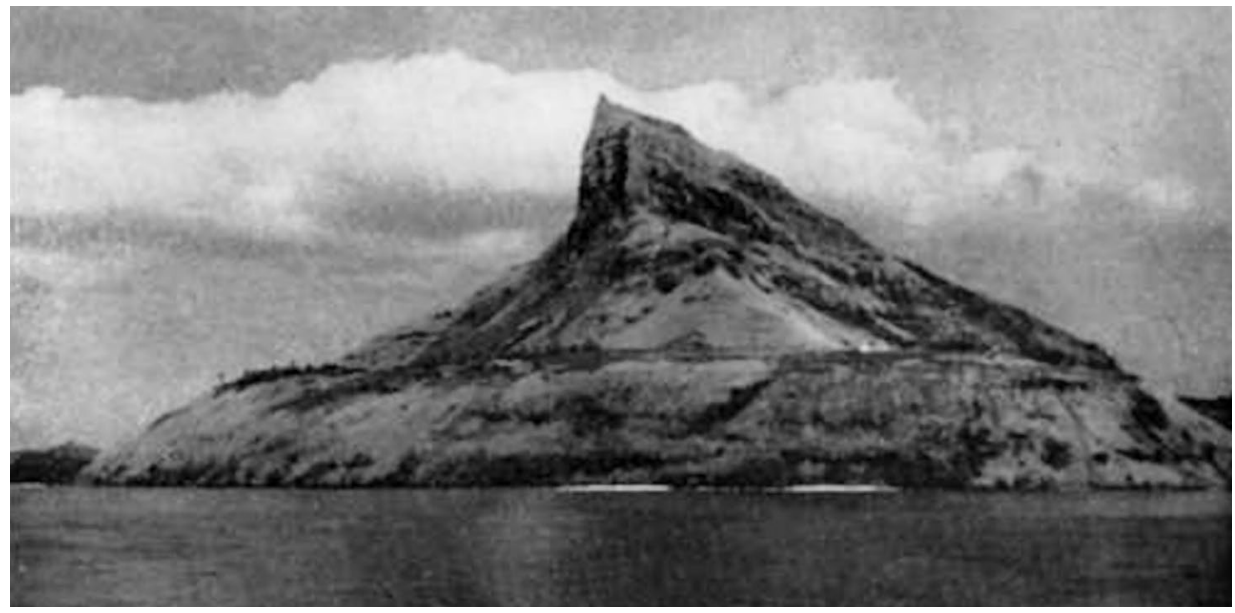

Figure 2.3 Mount Duff, Mangareva Island, early twentieth century.

The village Rikitea in the great bay is just out of site on the right. One notes the near-absence of trees, commented upon by both Buck (1938) and his Bishop Museum colleague Kenneth Emory, and an important context to Buck's discussion of Mangareva's ecology.

Source: Photo by Te Rangi Hiroa (Sir Peter Henry Buck). From New Zealand Electronic Text Collection under a Creative Commons licence, nzetc.victoria.ac.nz/tm/scholarly/BucViki-fig-BucViki_P017a.html.

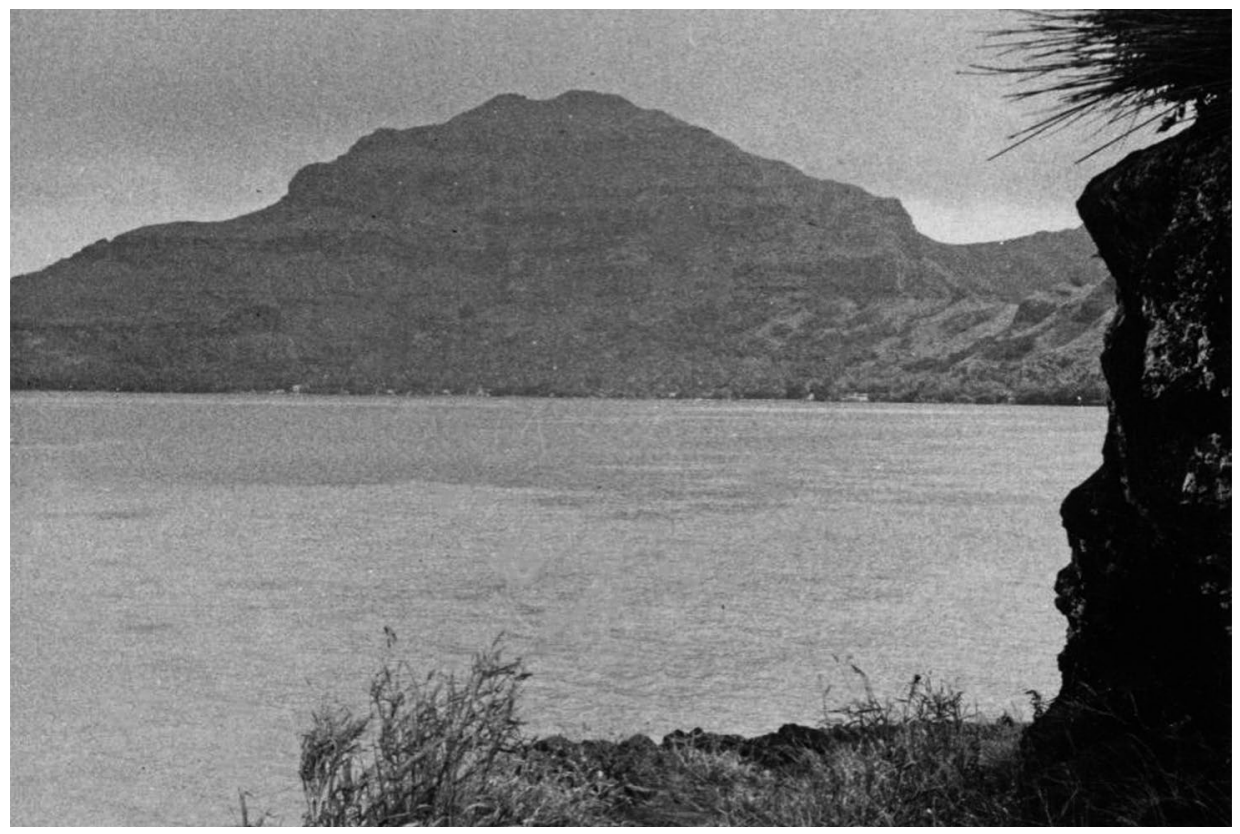

Figure 2.4 Mount Duff with Rikitea village and bay in foreground, just after mid-century yet prior to the massive forestry work of the territorial Service de l'Agriculture.

Source: Photo by Roger Curtis Green, 1960. From DigitalNZ archive under a share licence, www.digitalnz.org/ records/32431161?search[page]=3\&search[text]=mangareva. 


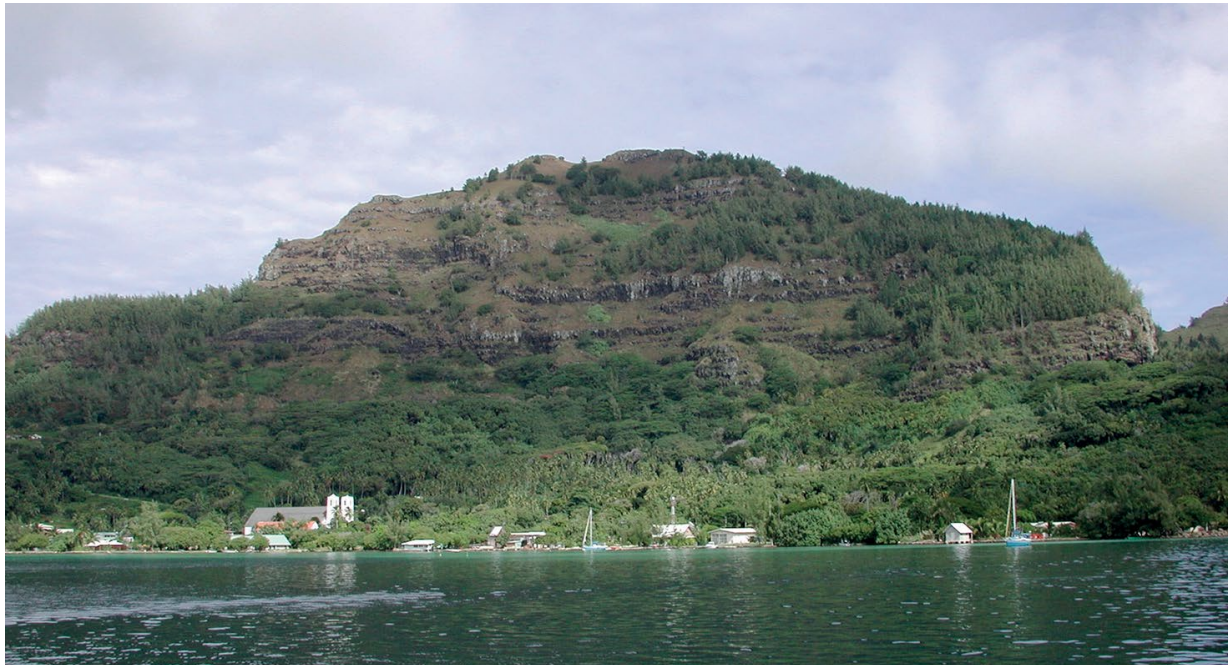

Figure 2.5 While near-shore cultivated gardens and bays retain a traditional verdure, Mount Duff and downslope plateaus are now heavily forested, largely as a result of the regional agricultural forestry service's efforts. Source: Photo by Alexander Mawyer, 2002.

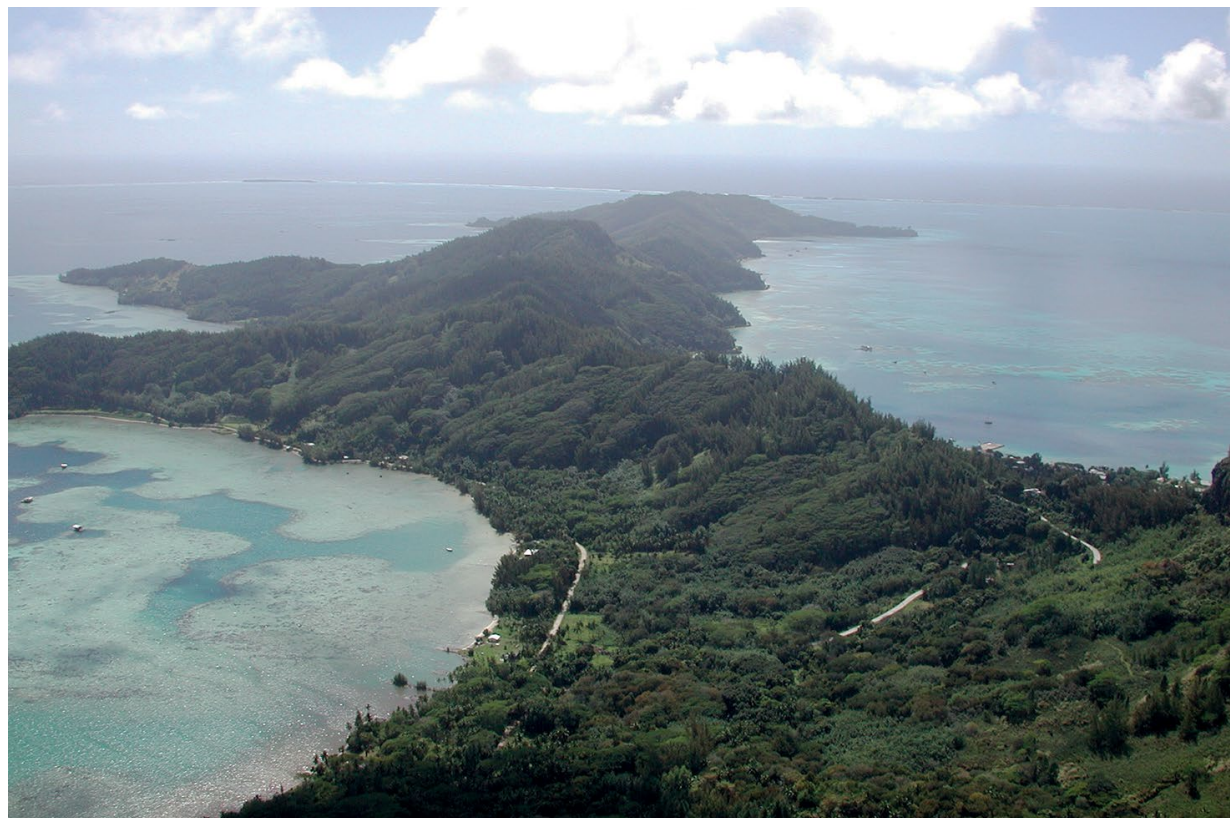

Figure 2.6 While the vertical face of Taraetukura (Mount Duff, Figure 2.5) evidences a significant shift towards coverage, the island's spine and downslope ridgeline from Mount Duff's peak, running north-east, are now remarkably forested and the change is striking relative to any point earlier in the twentieth century. 
Now the Gambier's population is burgeoning — 1,337 as of 2007 (ISPF 2011) and families are beginning to push back into the de-domesticated (previously cultivated) bays, producing all sorts of curious entanglements with history, since the contemporary 'bush' turns out previously to have been someone's house platform, imputed marae or papa sitting stone or backyard. Sometimes it turns out that the bush is covering up one or more charming French provincial quarried stone houses from the height of the Catholic instauration between 1834 and the 1870s, long abandoned and generally forgotten, leading the contemporary Mangarevan landowners to ponder questions of historic loss over several different periods - not only the loss of tradition but of modernity around 1850, which somehow did not last and was absorbed into vao space. Such layerings of historical complexes are not restricted to the architectural. The old coffee plantations and the most incredible raspberry plantation on the back of Mount Duff similarly reverted to a historically murky bush quality, as did the remaining orange trees isolated across the archipelago and closely observed in their use-rights. Together, these all reveal a quality of Tsingian weediness (Tsing 2005) ${ }^{9}$ in which these wooded terrains have become not only physically bushy, but also conceptually murky, socially fraught and affectively tangled.

In consequence of these histories, the ecosocial setting of the Gambier Islands, the relations between the places of the past and wild spaces, nature spaces, forest and bush, is not now easily disentangled. This tangled, weedy quality of the local understandings of the normative relations between Mangarevans and their islands' non-domesticated spaces became more visible in the years between 1999 and 2009, which were remarkable for the emergence of a new wave of highly domestic labour organised at the level of the 'akairiga (the household family), which began during these years to take back the vao, the de-domesticated spaces of the islands abandoned over the past 150 years and notable for the overgrown ruins of the Catholic instauration and the all but impassable tropical gnarl that surrounded them. Land-clearing work parties in which I participated on four islands - with individual families, 'akairiga, within groups of families claiming descent from the same ati, and with church groups representing the whole community - in 1999, 2002-03 and 2009 may have differed in the kinds of terrain from shore plots, to bay interiors and upland plateaus, and different historical distances from last moment of former habitation, but all shared a characteristic sort of conversation. Discussions of these de-built and de-cultivated spaces frequently and tangibly produce anxiety in many speakers at many ages of life, centred on the question of what the facts of de-domestication and wilding of previously domesticated lands imply for their own Mangarevan

9 'Weeds have been of little interest to conservationists; we think of them only as indicators of disturbance' (Tsing 2005: 174). 
identity and what might be called the descent-of-belonging or the inheritance of us-ness in conjunction with the, now generally, legal establishment of title to lands and the use of their resources.

Thus many folk in the Gambier today, old and young, have a complex relationship with the different sorts of island spaces common sense tells me to see as now-established forest with which they must engage in order to craft new homes on old lands. The issue, as differently positioned persons seemed to experience it, was thus the way that de-domestication seemed to erase or, at least, damage the descent through time of linkages to the past and its peoples - particularly their quality of true or authentic tika, Mangarevan-ness, with the unsettling implication that contemporary persons are vao ke, that is, social others. Again and again I have heard such questions posed: What should be understood of the decaying coffee plantations running up the ridges in the backs of the inhabited valleys of the main towns, the punui? What of the former church raspberry plantation, today difficult to reach, and free to all for the price of the effort to reach it, on the back of the island, i tua? What of the remaining orange trees, signs of futurity past here and there, each priceless? The 'ownership' of coconut groves, no longer cultivated? The few, modestly economised lychee? The actual vao rakau, wild, tangled, imposing? What is the place or role of the wild spaces in everyday life in the local conceptualisation of being-an-us, being Mangarevan? To whom do useful trees (coffee and orange, breadfruit, hau and miro) belong? To whom belong the forest-enclosed cultivars such as raspberry, signs of past domestications, from an era of collective possession and collective use? To whom belong those material things, legacies of past domestications, by forest obscured?

As in Harrison's epigraph at the start of this section, there was a historical collapse in the Gambier. But not of traditional Polynesian culture or society as Diamond (2005) would have it, and certainly not of Mangarevan culture of the longue durée. Rather, what collapsed was the post-contact colonial-theocratic order(ing) of things. Stone houses collapsed into ruins. Ancestors became others, plantations became plants, the vao became wilderness.

\section{Other People's Kaiga}

It is hard for us to imagine, several millennia later, how the return of the forests was experienced as a cataclysm by many of our stone-age ancestors [after the last ice age] (Harrison 1992: 197).

Everyday life in the Gambier rests on a fabric of labour in the various sites, commercial and domestic, sacred and civic, terrestrial and maritime, that make up the manifest of human practices in these islands - this is the kernel of 
the long-enduring sense of domestication in its anthropological interpolation, that the human is a technologist, a reworker and remaker of an unruly nature, a pacifier of the world as given. We dwell in worlds of our own modification as Homo domesticans. Sociality can be loosely characterised as a function of work layered over a patina of private familial activities and occasional, generally predictable, civic activities annually centred around the summer cultural festival Te Tiurai. ${ }^{10}$ So much for the thrum and throb of everyday life, social relations coalescing out of institutions of encounter and engagement in these various sites. Underneath all of this activity, Mandeville's buzzing hive, rests kinship, land and the social relationships affirming or denying shared rights to its use, particularly the use of its plant resources, the literal fruits of the land.

That land is politics is a banality that hardly requires comment. Since the unfolding of the rule of Western law beginning during the nineteenth-century administration of the Mangarevan kingdom (Code Mangarévien 1870), French land law was increasingly imposed on the Gambier. But the legacy of precontact and nineteenth-century land tenures, informal understandings between individuals and the church about rights to lands and their products, and the changing biofacts of the island's 'natural' spaces have resulted in a murky situation bearing on the practical dimension of the domestic-undomesticated distinction, the use of lands and the vegetable resources found on them. ${ }^{11}$ The slippage between these two land tenure systems offers another perspective on undomesticated space. Nature's spaces, the contemporary wilds, are as contested now as they were in the centuries before contact with Europeans vastly expanded the variety and kinds of domestic foodstuffs available for cultivation in the Gambier, while coincidentally leading to the depeopling, deculturation and de-domestication of many of the archipelago's bays. In contemporary moments of everyday heightened significance, land disputes and land clearing, and construction and development, lead to personal and often intimate reflections on Mangarevan society, its generational and genealogical cohorts, and the meaning of the past in the present. The fallout is that kith and kin, to say nothing of neighbours almost inevitably more or less related (contemporary proximity predictably indicates past, if not present, kinship affinity), are

\footnotetext{
10 Te Tiurai (July) is preferred here to Te Heiva, which has specifically Tahitian overtones, locally problematic in the politics of inter-island personhood.

11 In principle, today a finite number of regional and national statutes govern land ownership and rights of use, property and propriety with respect to the lands of others. In practice, the situation is complicated and can be confounding. For instance, among other factors, the cultural order bearing on names of lands and names of persons may be more important to individuals thinking about the meaning of land and their rights to the products of the land. As a judge on Mangareva in 2002 as part of a multiyear process of settling title on Gambier lands affirmed, it is by no means certain that even the latest statutes which in theory have modernised the registration of property in French Polynesia will be resolvable by the courts within the time frame of five to ten years as anticipated by the Territorial Assembly. 'Perhaps', he wondered, 'thirty years will not be enough.' Until then, land tenure and the politics of the everyday that revolve around it will remain, he suggested, entangled in the legacy of multiple understandings, codes and practices.
} 
caught in a web of increasingly fraught relations as shared connections to $n u k u$, 'maternal lands', are transformed, as the land itself is being transformed by increasingly successful legal regimes into kaiga - mere 'land' in a legal sense. Such transformation further heightens for contemporary cultivators and domesticators their sense of a disconcertingly uncertain relation to legitimate inheritance or descent.

\section{Conclusion}

In response to the concept of forest in Oceania, this chapter suggests that at least part of the significance of this category can be its role in contributing to a critical reappraisal of nature spaces at the intersection of local and extra-local understandings of self and other, past and present, in the contemporary Pacific. As Hull (2006) notes in his intriguing Infinite Nature, there are myriad ways that people can relate to nature. The category of forest, forêt, tiarakau, is but one, as is vao, and attention to such categories does more than articulate how it is that nature is socially constructed, but offers a lens onto human practical relationships (themselves domesticated and undomesticated) with their lands and personhood.

Aside from its role in framing a dark romanticism in European literature and art (à la Melville or Gauguin), the forest in eastern Polynesia has been something of a categorical nullity. I suggest that this is surprising given the established importance of the early nineteenth-century sandalwood trade on some of this region's islands in establishing early structural conditions upon which many later social and political developments rested. Meanwhile, across archipelagoes of this region such as the Gambier, the critical ecosocial role played by breadfruit groves and the surrounding highly domesticated seaward lands prior to contact with European cultures appear rarely to have been perceived or anthropologically interpolated as forested in favour of conceptions of domesticated plantations for 'economic' trees and wildlands for all other ecosocial spaces in the islands. Uplands were seen as more or less undomesticated wilds of last resort, noneconomic, regardless of whether they were wooded or not.

This chapter suggests that the categories undergirding the process of sensemaking of nature spaces in these island contexts (both local and extra-local) have gotten bushy, or weedy in one of Tsing's (2005) senses. The changing biofacts of nature in the Gambier Islands have not merely resulted in the obscuring of the land under a patchwork of verdant weediness due to depopulation, de-domestication and late-twentieth-century new forestry projects, they have also resulted in an obscuring of locally salient intimate understandings of selves and others. The character of relatively non-domesticated forest as natural in the Western conceptual sense as a place where man is not is ultimately suspect 
in the Gambier, as it is perhaps elsewhere in the Pacific (if not everywhere humans have dwelt over the tumbling millennia). Significantly, local cultural understandings of nature spaces draw meaningful distinctions between kinds of domains with significant implications for human sentiment, practice and experience along domestic-wild categories.

That the concept of forest poses an ontological question in the Pacific is, as I think all of the pieces in this volume demonstrate, well established. That the fact of the forest poses a practical problem, or a matrix of issues, challenges and contestations, also seems evident. Like many readers across disciplines, I have been influenced by Harrison's (1992) superb reflection on the unfolding character of the forest for actual human populations and experience in European history, both for its particularity and applicability to the encounter with the foris, the outside, the verdant wilds, elsewhere and elsewhen. I argue that a central, and as elsewhere in the eastern Pacific too little discussed, aspect of the experience of the Gambier Islands since cultural contact with Europeans from the early nineteenth century has been a transformative process of de- and re-domestication. I propose that attention to the cyclical, dynamic character of this model of Pacific nature, including Pacific forests, can contribute to the disestablishment of too-narrow linear narratives of island development both before and after contact. Since that period, the process of the de- and re-domestication of the Gambier has been experienced in dimensions eminently symbolic, requiring conceptual adjustments as well as pragmatic responses.

The use of fruiting trees, bushes and vines, the sense of their place in the landscape, or their present use and rights thereto, even where they are and what they mean, is today erupting into everyday conversations and practices and informing varying intense encounters in the micropolitics of intra-island society. Discussion of the meaning of such de-built and de-cultivated spaces hinge everyday conversations to politically heightened issues of civility, sociality and Mangarevan identity. The Mangarevan word for forest, tiarakau, points more or less to land planted with trees, with an emphasis on agency, utilisation, use-value and other degrees of domestication somewhat at odds with core features of the category 'forest' in Western and, I think, much anthropological conception. In this chapter, I have drawn attention to the social significance of what otherwise might appear to be forest in the Gambier as vao, an outside that is in structural tension with the inside, the Mangarevan 'we', both practically as a matter of land-use and property rights, and conceptually in the way in which a sense of self undergirds collective existence put at stake. In this part of the Pacific, as perhaps elsewhere in the region, the enduring absence of a categorical or conceptual dichotomy between lands and persons, as metonymical between nature and culture, yields a characteristic form to this problem. What is the vao now? Are our spaces our own? Are we who we thought we are when our woods are wildlands? 


\section{References}

Anderson, A., E. Conte, P. Kirch and M. Weisler, 2003. 'Cultural Chronology in Mangareva (Gambier Islands), French Polynesia: Evidence from Recent Radiocarbon Dating.' Journal of the Polynesian Society 112(2): 119-40.

Buck, P.H., 1938. Ethnology of Mangareva. Honolulu: Bernice P. Bishop Museum (Bulletin 157).

CESCEN, 2006. 'Rapport de la Commission d'Enquête sur les Conséquences des Essais Nucléaires en Polynésie Française par l'Assemblée Territoriale de la Polynésie Française.'

Code Mangarévien, 1870. Manuscript.

Collingwood, R.G., 1945. The Idea of Nature. Oxford: Oxford University Press.

Delbos, J.-P., 2002. La Mission du Bout du Monde: La Fantastique Aventure des Bâtisseurs de Cathédrales dans l'Archipel des Gambier. Papeete: Éd. de Tahiti.

Dening, G., 1988. Islands and Beaches: Discourse on a Silent Land: Marquesas, 1774-1880. Chicago: Dorsey Press.

Descola, P., 1996. 'Constructing Natures: Symbolic Ecology and Social Practice.' In P. Descola and G. Pálsson (eds), Nature and Society: Anthropological Perspectives. New York: Routledge.

Diamond, J., 2005. Collapse: How Societies Choose to Fail or Succeed. New York: Penguin.

Douglas, B., 2009. 'In the Event: Indigenous Countersigns and the Ethnohistory of Voyaging.' In M. Jolly, S. Tcherkézoff and D. Tryon (eds), Oceanic Encounters: Exchange, Desire, Violence. Canberra: ANU E Press.

Escobar, A., 2008. Territories of Difference: Place, Movements, Life, Redes. Durham (NC): Duke University Press.

Goldman, I., 1955. 'Status Rivalry and Cultural Evolution in Polynesia.' American Anthropologist 57(3): 473-502.

Goldman, I., 1957. 'Cultural Evolution in Polynesia: A Reply to Criticism.' The Journal of the Polynesian Society 66(2): 156-64.

Goldman, I., 1958. 'Social Stratification and Cultural Evolution in Polynesia.' Ethnohistory 5(3): 242-9. 
Goyau, L.G., 1928. Le Premier Demi-siècle de l'Apostolat des Picpuciens aux Iles Gambier. Paris: Gabriel Beauchesne.

Harrison, R.P., 1992. Forests: The Shadow of Civilization. Chicago: University of Chicago Press.

Hau'ofa, E., 1993. 'Our Sea of Islands.' In E. Waddell, V. Naidu and E. Hau'ofa (eds), A New Oceania: Rediscovering Our Sea of Islands. Suva: University of the South Pacific, School of Social and Economic Development.

Hull, B., 2006. Infinite Nature. Chicago: University of Chicago Press.

Hviding, E., 1996. 'Nature, Culture, Magic, Science: On Meta-Languages for Comparison in Cultural Ecology.' In P. Descola and G. Pálsson (eds), Nature and Society: Anthropological Perspectives. New York: Routledge.

Hviding, E., 2003. 'Both Sides of the Beach: Knowledges of Nature in Oceania.' In H. Selin (ed.), Nature across Cultures: Views of Nature and the Environment in Non-Western Cultures. Dordrecht: Kluwer Academic Publishers.

ISPF (Institut de la Statistique de la Polynésie Française), 2011. www.ispf.pf.

Jolly, M., 2009. 'The Sediment of Voyages: Re-Membering Quirós, Bougainville and Cook in Vanuatu.' In M. Jolly, S. Tcherkézoff and D. Tryon (eds), Oceanic Encounters: Exchange, Desire, Violence. Canberra: ANU E Press.

Jolly, M., S. Tcherkézoff and D. Tryon (eds), 2009. Oceanic Encounters: Exchange, Desire, Violence. Canberra: ANU E Press.

Kirch P., 1989. The Evolution of the Polynesian Chiefdoms. Cambridge: Cambridge University Press (New Studies in Archaeology).

Kirch, P., 2002. 'Three Islands and an Archipelago: Reciprocal Interactions between Humans and Island Ecosystems in Polynesia.' Earth and Environmental Science Transactions of the Royal Society of Edinburgh 98(1): 85-99.

Kirch, P., 2007. On the Road of the Winds: An Archaeological History of the Pacific Islands before European Contact. Berkeley: University of California Press.

Kirch, P.V. and J.-L. Rallu (eds), 2007. The Growth and Collapse of Pacific Island Societies: Archaeological and Demographic Perspectives. Honolulu: University of Hawai'i Press.

Kirch, P. and M. Sahlins, 1994. Anahulu: The Anthropology of History in the Kingdom of Hawaii, Volume 1: Historical Ethnography. Chicago: University of Chicago Press. 
Laval, H., 1938. Mangareva, l'Histoire Ancienne d'un Peuple Polynésien. Paris: Librairie Orientale Paul Geuther.

Laval, H., 1968. Mémoires pour Servir à l'Histoire de Mangareva, Ère Chrétienne 1834-1871. Paris: Musée de l'Homme (Publications de la Société des Océanistes 15).

Lotz, C., 2005. 'From Nature to Culture? Diogenes and Philosophical Anthropology.' Human Studies 28(1): 41-56.

Malinowski, B., 1984 [1922]. Argonauts of the Western Pacific. Long Grove: Waveland Press.

Rensch, K., 1991. Tikianario Arani-Mangareva/Dictionaire MangareveinFrançaise. Canberra: Archipelago Press.

Sahlins, M., 1958. Social Stratification in Polynesia. Seattle: University of Washington Press (Monographs of the American Ethnological Society 29).

Selin, H. (ed.), 2003. Nature across Cultures: Views of Nature and the Environment in Non-Western Cultures. Dordrecht: Kluwer Academic Publishers.

Smith, B., 1985. European Vision and the South Pacific. New Haven (CT): Yale University Press.

Tregear, E. 1899. A Dictionary of Mangareva (or Gambier Islands). Wellington: John Mackay, Government Printing Office.

Tsing, A., 2005. Friction: An Ethnography of Global Connection. Princeton (NJ): Princeton University Press.

Vallaux, F., 1994. Mangareva et les Gambier. Tahiti: Etablissement Territorial d'Achats Groupes.

Vogel, S., 1996. Against Nature: The Concept of Nature in Critical Theory. Albany (NY): SUNY Press. 
This text is taken from Tropical Forests of Oceania: Anthropological Perspectives, edited by Joshua A. Bell, Paige West and Colin Filer, published 2015 by ANU Press, The Australian National University, Canberra, Australia. 